South African Review of Sociology - 15 March 2011

\title{
LIFE IN A SOUTH AFRICAN HOUSEHOLD, 1909-1923: CHANGING PATTERNS IN LEISURE AND SERVITUDE
}

\author{
IAN VAN DER WAAG \\ Department of Military History \\ Stellenbosch University \\ ian@ma2.sun.ac.za
}

Domestic history in South Africa is largely an unploughed field. Yet, for much of South Africa's past, households were the places where concerns about class, gender and race intersected, at a very close, personal, level. Moreover, it was in the residences of the power elite that the contradictions between the ideas of a migrant aristocracy, notions of empire, and the practical needs for the maintenance of an ostentatious lifestyle, are revealed. In this paper, I use one elite household in Johannesburg (1909-1923) as a lens through which to explore a variety of these domestic experiences and expose the nexus between race, class and empire in South African domestic history at the turn of the twentieth century and so further develop ideas first advanced in my article in the Journal of Family History (2007).

Keywords: race, class, empire, household, servants, life, leisure, domestic history

\section{SETTING THE TABLE}

South Africa underwent a dramatic transformation during the first quarter of the twentieth century. These years, commencing with much of the country caught in the grip of a total war and ending with the Rand convulsed by a violent strike and its brutal suppression, marked the creation of the South African state, the alignment of capital and government, the further development of an exclusive, white, South African nationalism and increasingly by conflict and division among her peoples. It is the core of what seems to be a coherent historical period extending from approximately 1850 to 1960 . This change was significant and allpervading. It played out all through country as a continual dispute between men and women, lawmakers and journalists, the privileged and the serving classes. Yet, while the household was the primary place where race, class and gender come together under one roof, omniscience and a dearth of sources, makes the study of domestic history difficult. The study of a single household, used as a lens through which to study these and other processes, both within South Africa and the wider British world, permits a narrower focus and a more manageable area. In this regard, the Wyndham household in Johannesburg is a useful lens, for Hugh and Maud Wyndham were great correspondents, his letters perhaps somewhat mundane when contrasted with hers, and much of the family correspondence has been preserved.

While there has been some recent work focussing on comparative, exploitative, colonial contexts (Haskins 2001; Jacobs 2007; Martinez 2007; Sager 2007; Ally 2009) there has been very little South African, historical analysis since 1982 when Charles van 
Onselen first delivered his magnificent study on 'the witches of suburbia.' (2001: 205-74) Moreover, as David Cannadine has reminded us, the British Empire and its constituent parts were in many ways inseparable and should be studied as a seamless whole. During the zenith of empire, from about 1850 to the end of the Second World War, 'the British world' embraced complex, layered, interlocking hierarchical societies reflecting the social pecking order that existed in what expatriates called 'the home country.' (Cannadine 1998) This vast array of hierarchies was 'brought together, interconnected, unified and sacralized' by the monarchy. (Cannadine 2002: 122). Millions of loyal subjects only saw the monarch periodically and, in between royal visits, majesty was embodied by a permanent representative, in the dominions a governor-general, who held court, opened parliament, and received an ongoing stream of travelling aristocrats, the locally-connected, and the new superwealthy who desired to wash away the newness of their money with champagne at Government House. Colonial peerages were created (the first chief justice of South Africa became Lord de Villiers in 1910) and these men together with migrant aristocrats were affirmed in the prestigious, red-bound volumes of Burke's Peerage. Colonial gentlemen, aspiring to some recognition but without established rank, jostled themselves into Burke's Colonial Gentry; fourteen South African families found success and were listed by 1895.

\section{INTRODUCING THE FAMILY}

The existence of much of the correspondence generated by Hugh Archibald Wyndham (18771963) and his wife, Maud Lyttelton (1880-1952), is a clear indication that this was no ordinary household. Both were educated and Maud was able to revel in her literary transactions with a wide number of their relatives and social connections, many of whom crammed the pages of the Peerage. Their families were noble and landed and their interests were transnational and strongly intertwined. Hugh and Maud shared connections with half a dozen British prime ministers and a host of colonial governors. Hugh's father, Lord Leconfield, was one of the richest men in Britain, while, Rosebery, Queen Victoria's prime minister and from whom Hugh received his second name of Archibald, was Hugh's uncle and Petworth House, where Hugh was born, had been in the family for more than 700 years. (van der Waag 2002: 316, 335)

However, as a younger son, Hugh's fortune had to be mostly of his own making, although he received a solid, public-school education and an annuity to make his way in the world, and he could exploit family connections by making himself indispensable to powerful relatives or by marriage to an heiress or finding success in a career. (Stone 1986: 148). Wyndham went through these steps in succession. First, a well-placed cousin eased his appointment to Milner's staff in South Africa in 1901. Then, in 1908, having entered South African politics, he married Maud, who was from a well-connected, 'establishment family.' Her brother Jack had served as Selborne’s ADC, Alfred Lyttelton was an uncle, and William Gladstone, South Africa's first governor general (1910-14), a cousin. (Cannadine 1996: 237; Anon 1908) The Wyndhams, therefore, had direct access to Government House and enjoyed an unofficial status within the 'imperial set' in South Africa.

Although Hugh had left imperial service in 1903, he had remained in the Transvaal and acquired Kromdraai, a farm near Standerton which he developed into an English-style estate. Here he built a country house, bred horses, wrote extensively, commanded his own 
regiment, and attempted to organise the 'British' settlers ahead of the grant of selfgovernment. After an unsuccessful attempt at Standerton in 1907, he won Turffontein as a Unionist in 1910. The open space and emphasis on agriculture presented men like Wyndham with the opportunity to recreate in the dominions a lifestyle that was vanishing in Britain. They entertained lavishly, paraded at the races and the opening of local legislatures, officered the local volunteer regiments, created British-styled clubs and societies, and demanded more than a measure of deference from the local inhabitants. (Cannadine 2002: 2729) Such theatricality and display of British 'energy, success, and apparent omniscience' mesmerised the populations of colonial states and reinforced the thin red line (Hyam 1993: 281-2; Darwin 1997: 617). Wyndham patronised the Transvaal Philosophical Society and the St George's Society and served as a justice of the peace and member of the Standerton Liquor Licensing Court. He was at times chairman of the Victoria League of South Africa as well as the unofficial head of the Round Table movement in southern Africa, steward of the South African Jockey Club and a lay member of the provincial synod of the Anglican Church. Maud served periodically as president of the Women's Unionist Association, was a member of the executive of the Victoria League and on the executive of the National Council of Women.

Maud, Hugh reported to his mother, 'worked wonders in Johannesburg Society [and broke] through various cast iron cliques. ${ }^{1}$ But with a title and connections (her aunt, Meriel Talbot was also the Victoria League's highly competent UK-based secretary) this was not too difficult. (Riedi 2002: 576) However, of great concern to imperialists in England and South Africa, was the materialism of Johannesburg and the division among Britons there. ${ }^{2}$ The Selborne's daughter, Mabel Palmer, told Maud in August 1905, that 'no one [in Johannesburg] takes the faintest interest in anything outside what effects $£$.s.d. in the mines \& shares etc. Everything \& everyone turns on these 3 letters. I confess I don't think Johannesburg people are calculated to impress one imperially! ${ }^{3}$

These were sentiments shared by Jack Lyttelton, who grumbled to Maud that the town was 'largely peopled by cats of the most cattish order and all divided up into factions. ${ }^{4}$ Women's organisations proliferated through dissent and fission. The Federation of British Women was established in 1906, apparently under the auspices of the Progressive Association, and contained 'a great many conflicting elements, not only of parties but of the different personalities of the various officials. ${ }^{5}$ Within months, Marguerite Chaplin was part of the move to establish 'the kind of League' she thought was needed: not formed on party lines but on principle. Yet, the principles proposed (imperial ascendancy and the maintenance of the British Flag in South Africa, for one) placed the British Women's League squarely in the political arena and with little to differ it from the Federation of British Women. ${ }^{6}$ Within a year, the British Women's League was in trouble. Milner intervened in an attempt to save the League ('I think the mere fact of keeping the women,

Hugh Wyndham to Lady Leconfield, 19 Apr 1909, WSRO: PHA.

2 Alfred Milner to Marguerite Chaplin, 24 Dec 1907 and 5 Jan 1908, UCT: BC831 Drummond Chaplin Collection.

Lady Mabel Palmer to Maud Lyttelton, 18 Aug 1905, HHA 2/21/30.

Jack Lyttelton to Maud Lyttelton, 2 Oct 1905, HHA 2/21/37.

Diary of Marguerite Chaplin, undated, UCT: BC831 Drummond Chaplin Collection.

May Cooke to Marguerite Chaplin, 25 Feb 1907, UCT: BC831 Drummond Chaplin Collection. 
where sympathies are, in a broad sense, British, together, must be of much use ${ }^{\text {,7) }}$ but, even this, was only of momentary effect. British women, the gatekeepers of their societies, did much to undermine the ideals of empire by harbouring grudges and clinging to notions of class and status.

Maud was a strong woman, whose life revolved around three or four main interests; trying to produce an heir to the Leconfield title and estates, dabbling actively in her family's history, promoting her husband's political career, and the conduct of her wideranging correspondence, in which she revelled. ${ }^{8}$ Continuous communication allowed the imperial elite to engage in debate on a range of issues, from high politics to the management of large households and the handling of servants. The last matter, at first glance perhaps mundane, was, as we shall see, of tremendous importance to the ruling and employing classes. At the turn of the century there was still much stability between the human groups in the British Empire. The bulk of the population in the United Kingdom was in domestic service and, as late as 1911, domestic service remained by far the largest single category of female employment, having almost doubled in size since 1851 to 2,127,000 (39 per cent of the total occupied female population) (Royle 1987: 91-2, 223, 281). For many working-class men and unmarried women domestic service was the most available form of employment. The empire brought increased opportunity and vast swathes of the serving class migrated to the settlement dominions, where they served a gentry increasingly intimidated by nationalism, labour and syndicalism, and egalitarianism, processes that threatened the concord and constancy of the Edwardian world.

\section{THE DOMESTIC SETTING}

The household has several elements; there is the family, often augmented by visiting relatives from Britain, who occupy the house, which is the second element. The Wyndham residence in Johannesburg is still there, on Parktown ridge alongside the Johannesburg General Hospital and hemmed in by the M1 motorway and steady CBD creep. The house was more salubrious in 1909. Its grounds and gardens were more extensive. Guests could walk down the hill into Saxonwold or along the ridge to the homes of the Randlords. The stable block accommodated several good horses, as well as a spanking motor car. The reception rooms and veranda, with sweeping views over the veldt to Pretoria, were first-rate for soirees and political gatherings.

The Wyndhams purchased the mansion, then called Emoyeni, from H.C. Hull, the Transvaal finance minister, in 1909. Furniture, carpets and drapes were bought in London and the place, renamed Wyndhams, was refurbished, primarily by Maud with the assistance of Hugh's mother. Linoleum was laid down in all the passages and landings, the walls were distempered and the dining room transformed from 'a howling wilderness.' was stocked with appropriate books; Lady Leconfield arrived in February 1910 armed with a Burke's Peerage and a Who's Who, essential tomes in any patrician library. Further renovation followed in 1912, when the plans were drawn by Herbert Baker, and the hall

\footnotetext{
$7 \quad$ Milner to Marguerite Chaplin, 5 Jan 1908, UCT: BC831 Drummond Chaplin Collection.

$8 \quad$ Lady Cobham to Maud Wyndham, 29 Nov 1918 and 7 Dec 1918, University of Birmingham Libraries: Masterman Papers.

$9 \quad$ Maud Wyndham to Lady Leconfield, 26 Dec 1909, WSRO: PHA.
} 
and smoking room were refurbished, the staircase was rebuilt, some of the bedrooms were refashioned, and three new rooms were added. A lesser renovation followed in 1914.

Wyndhams was luxuriously furnished, containing masterpieces and objets d'art, some inherited, and others accumulated gradually on their travels. A Zoffany and a Barker of Bath greeted visitors in the hall; while, in the dining room, hung a Woolton, a Raeburn and a Zuccarelli. Maud's sitting room, part of the 1914 refurbishment, gave her a space of her own ('a special perch') where she could sit and read and, of course, write. Here the walls were bright green, the paintings included a Farington and a Vandeveldt Jr, while the rest of the room was taken up with bookshelves and a very large mirror they had acquired in Stockholm.

Maud was at first happy to fulfil the expectations of wife. She was content to please Hugh, run an efficient household and play the roles of graceful hostess, chiefly at their Parktown residence and occasionally at Kromdraai. Maud had time for leisure, which she spent in conversation with family and friends, reading, the maintenance of her impressive correspondence, and the production of three handsome volumes of Lyttelton family history. (Wyndham 1912, 1924) But, she soon tired of this existence. ${ }^{10}$ Patrick Duncan, an otherwise imperceptive observer of women, felt that what Maud wanted most was 'some person or motor which would make her do things and pull her out of the centre of indifference in which she seems to live. ${ }^{11}$ Hugh, it would seem, was incapable of playing such a role.

Life for the Wyndhams followed a certain rhythm. The year started with the cricket and polo season. In mid-January they moved down to Cape Town for the parliamentary session (Hugh was re-elected in 1915) when they sometimes resided in the Mount Nelson. When the House rose, normally in May, sometimes June, they returned to Johannesburg, but would break away frequently. Away from the political circuit, there was Kromdraai and the horses, which raced regularly at Turffontein and Greyville. They received visitors each year, often family, who adjusted to this rhythm. Sometimes the Wyndhams accompanied visitors on travels within southern Africa, although this did not have the excitement of the country house circuit or the London season and Maud (who never quite developed the love for South Africa 'the rest of her family' $\mathrm{did}^{12}$ ) looked forward each year to her visits to the United Kingdom.

Wyndhams was, of course, built for entertaining. Hugh and Maud gave lavish garden parties and weekend 'at homes'. The first garden party was hosted in March 1910 and from then regularly. The Gladstones were frequent guests, as were a variety of military men and the leadership of the Victoria League and the Unionist Party of South Africa. Some stayed over, but never Hugh's electorate; they received tea and cake in Turffontein. (van der Waag 2003: 142-44) Social distance separated the Wyndhams and their companions from all that was 'dull' and 'not a very exciting.' (Dagut 1997: 4, 8) Maud later admitted that she found it 'tiresome' that, in South Africa, all white women, regardless of background, were 'ladies', a title set aside in her world for the wife of a peer and the daughters of the higher orders of the nobility. ${ }^{13}$ The constant passage of visitors (some of

\footnotetext{
10 Rachel Lyttelton to Lady Cobham, 3 Oct 1910, HHA 2/5/2.

Patrick Duncan to Lady Selborne, 27 June 1910, UCT: BC294 Duncan Papers, J1.2.17.

Lady Selborne to Patrick Duncan, 19 Oct 1907, UCT: BC294 Duncan papers, D4.1.2. Hugh Wyndham to Lady Leconfield, 23 Sep 1915, WSRO: PHA.
} 
whom might stay over for the night, others for several weeks) demanded a staff of servants. They are the third element of the household.

\section{BELOW STAIRS}

The servants, who were required to support this lifestyle, were an invisible yet all-seeing element that lived and largely worked 'below the stairs.' The servant world is opaque transnationally. (McKeon 2005) But we do know that Hugh, while a Johannesburg bachelor, kept a small household; only a cook and a housemaid. Maud, soon after their marriage and despite Hugh's ambition to maintain his 'limited \& very select household ${ }^{\text {, }}$, set about getting the house into order and appointing additional servants. ${ }^{15}$

\section{Types of servants - different categories - individuals}

There were many types of servants at Wyndhams, all graded according to their function. While the exact number is difficult to fix, a close scrutiny of letters at Petworth and Hagley allow some conclusions. By 1914 there were at least twelve servants; a butler, a cook, a lady's maid, two housemaids, a parlourmaid, a chauffeur and three 'houseboys', in addition to a kitchen 'boy', a pantry 'boy' and a gardener. This was not excessive by Parktown standards. (van Onselen 2001: 232) Moreover, two of Hugh's brothers had 32 and 17 household servants each. (Blackwell 1981: 183-200; Egremont 1969: 14)

\section{[FIGURE 1]}

The highest-ranking Wyndham servant was the butler, who was in charge of the other servants and received a salary of $£ 10$. His duties varied. He was in charge of the silver and plate, supervised their cleaning, and guarded against theft. He cared for Hugh's clothing, shined his shoes and boots, and made sure Hugh looked good at all times. A good butler was prompt, had an intimate knowledge of the family, and was unobtrusive but always at hand. Failure to attain these virtues sometimes brought ridicule. Maud's brother, Jack Lyttelton, when Selborne's ADC, described the butler at Government House as 'the most fatuous idiot ... with the manners of a wart hog. ${ }^{16}$

While there is no evidence that Wright was ever found 'fuddled' (the butler was also in charge of the cellar), he did have one vice and that was dressing too smartly. Some of the qualifications for butler were good looks and a good physique and, to be sure, to be well dressed himself, but, very importantly, was not to outperform his master. Wright, a Guards reservist, was 'a fine young man beautifully dressed, far better every day than Hugh's best effort', which, by Maud's evidence, was not difficult to achieve. ${ }^{17}$ By all accounts, and even those of the cook, who was his nemesis, Wright was an exceptionally

$14 \quad$ Hugh Wyndham to Lady Leconfield, 1 Nov 1909, WSRO: PHA.

15 Maud Wyndham to Lady Leconfield, 12 Dec 1909, WSRO: PHA.

16 Jack Lyttelton to Maud Lyttelton, 4 Sep 1905, HHA 2/21/31. Rachel Lyttelton, who visited her sister and brother-in-law in 1910 and knew their chauffeur, noted to her mother that the motor was 'rather dilapidated \& Pearson hasn't cut his hair since I last saw him.' See Rachel Lyttelton to Lady Cobham, 3 Oct 1910, HHA 2/5/2.

$17 \quad$ Maud Wyndham to Lord Cobham, 5 May 1912, HHA 2/34/33; Maud Wyndham to Lady Leconfield, 29 May 1912, WSRO: PHA. 
good butler. He studied the Wyndhams, which Maud thought 'a comfort to hear', knew their routines, their wants and their pleasures, and was always at hand to provide them. ${ }^{18}$ The Wyndhams hoped to retain Wright's services, but this ended in 1914 when he was called up to serve in the Great War.

The highest-ranking female servant in the Wyndham household was the cook, who earned $£ 9$ per month. She kept the keys to the store, kept the household books and accounts, ordered in food and supplies, and supervised the maids. She very much ran the house, yet was customarily subordinate to the butler. The cook was most often a widow, but certainly expected to be 'a steady middle-aged woman ... morally exemplary and assiduous to the harmony, comfort, and economy of the family.' (Horn 1975: 54) Yet, the Wyndhams seemingly encountered several 'troublesome' cooks: from Mrs Booker dismissed in 1909 for overspending and poor economy to Mrs Gray dismissed for her bickering, and then the fraulein who was forced to leave when the war broke out in $1914 .{ }^{19}$

The cook had several kitchen helpers to support her. There was always a kitchen maid to assist with food preparation and a scullery maid (the lowest of the female servants) to clean the pots and pans, a particularly gruelling job after a large party. The butler also had his staff, which numbered at least one housemaid and probably as many as three socalled 'houseboys', the latter fulfilling the function of footmen: they laid the table, waited at table, served tea, answered the door and assisted the butler generally. The housemaids swept, dusted, polished, cleaned, and washed from dawn to dusk, often with the help of the 'houseboys.' There seems to have been little difference between the wages of a housemaid and 'houseboy': in 1905 a housemaid in Johannesburg might have earned between $£ 4$ and $£ 5$, a wage a 'houseboy' reasonably expected in 1906. (van Onselen 2001: 215-16) Yet, a white housemaid was by far preferred, and particularly as a means to limit the corners of the house where the 'houseboy' might penetrate. (Anon 1920c: 1) Extra staff was contracted for large events. An additional cook and eight waiters were hired in for a Unionist Congress soiree when 200 guests were received in November 1912. ${ }^{20}$

Maud also had a lady's maid, a personal attendant, who was responsible for Maud's appearance, attended to her boudoir and wardrobe, and repaired her clothes. Maud had an excellent lady's maid in Murphie, who left Wyndhams in December 1915 to set up a dressmaking business in the town. Maclean, her wartime lady's maid, came from Government House, where she had served the Buxton girls. She was there to wait on Maud 'on one hand \& foot, button every button \& fiddle abt one's things for ever.'21

Servants accompanied the Wyndhams to Cape Town for the parliamentary session. Maud's lady's maid invariably accompanied them to the Mount Nelson, and if staying in rented accommodation the cook and housemaid were added. No domestic servants were maintained at Kromdraai, which was left in the care of Wyndham's agent and his farm staff. However, whenever the Wyndhams went to Kromdraai, some servants accompanied them, something they apparently enjoyed. (van der Waag 2007: 269)

\footnotetext{
$18 \quad$ Maud Wyndham to Lady Leconfield, 29 June 1912, WSRO: PHA.

19 Maud Wyndham to Lady Leconfield, 26 Feb 1909, WSRO: PHA.

20 Hugh Wyndham to Lady Leconfield, 17 Nov 1912, WSRO: PHA; Maud Wyndham to Lady Leconfield, 17 Nov 1912, WSRO: PHA.

$21 \quad$ Maud Wyndham to Lady Leconfield, 21 July 1917, WSRO: PHA.
} 


\section{Hiring and firing}

The Wyndhams recruited servants in several ways, one of which was directly from other good households. Hugh's chauffeur had driven Hull and, in 1913, he appointed a cook who had served the Bishop of Winchester. Government House was the source of at least one parlourmaid (1902), a lady's maid (1915), and a cook (1916). But good antecedents went only so far. As Maud complained in 1909, one of the maids, who gave 'a lot of trouble', 'hurled the Earl of Berkeley at me whose parlourmaid she had been. ${ }^{22}$

The South African Expansion Committee and its successor, the South African Colonisation Society, together with similar immigration societies, perhaps the preferred means of less well-heeled employers, was another very useful vehicle for obtaining servants. Moreover, the importation of white staff had a broader imperial objective for it grew the loyal British working class while releasing black 'houseboys' for the mines. Such servants were expected to sign a contract for a year or more in return for the passage, and the vetting of the agency supposedly assured success. As McKeon (2005: 663) has noted, domestic service was 'notoriously one step away from prostitution' and such recruitment was not without its problems: 'the Colonisation Society failed to supply both the quantity and quality of servant demanded in Johannesburg.' (van Onselen 2001: 32, 217-18, 243) Many ladies, it seems, used the agency for passage to new opportunities that offered better financial reward. Hugh had experience of this in 1902, when he sourced a cook who upon arrival 'was discovered to be such a low character' that he thought it inadvisable to allow her to proceed to Johannesburg. ${ }^{23}$ He never dealt with the immigration societies again.

A third alternative was a personal visit to the recruiting registries in Britain in the hope of 'finding a treasure.' This the Wyndhams did in April 1912, when practically all the servants were replaced. While registry fees were often high, contract-bound servants were something of a guarantee in a labour scarce Johannesburg. However, conflict arose when the expectations created by the registry or society were not met by the employer, which gave rise to injured looks, elaborate respectfulness and talk of broken promises. (van Onselen 2001: 215)

The family and social network also produced servants, and the Wyndhams, although remote in South Africa, were well-placed. In 1912 Hugh's sister and brother-inlaw, Ivor and Tiny Maxse, secured Wright, the butler, who had served under Maxse in the Grenadier Guards. Maud, in turn, advertised the availability of servants and, in 1917, recruited 'two black boys' for the wife of the Archbishop of Cape Town. ${ }^{24}$

A fifth option was to recruit from a family already in service. This Hugh did at Kromdraai, where the whole Spiller family worked for him. But the danger of employing a family group was a mass desertion if there was a fall-out with any one of them. This happened in 1906, when the Spillers left him in a body, but did not prevent Wyndham from employing another couple, the Ruxtons, at Kromdraai. Finally, in some cases, recruitment was left to the servants. There is a reference to the butler's intervention in Lady Leconfield's household when a footman had to be replaced promptly.

There were several reasons for the severance of servants. These ranged from bad interpersonal relationships, with the employers and other servants, to the hunt for better

\footnotetext{
22 Maud Wyndham to Lady Leconfield, 30 Apr 1909, WSRO: PHA.

23 Hugh Wyndham to Mary Maxse, 21 June 1902, WSRO: Maxse Papers 50.

$24 \quad$ Maud Wyndham to Lady Leconfield, 10 Nov 1917, WSRO: PHA.
} 
prospects and economy. The Wyndhams also closed their Parktown residence when they left on their regular, extended, pre-war visits to Britain and the continent. This not only saved the household expenses, but also gave them an opportunity to replace 'troublesome' servants on a regular basis. The servant was invariably dismissed in South Africa, while candidates were interviewed and hired in Britain, the intervening months being a saving on wages. Those servants who 'gave satisfaction' ('in their horrible vernacular'), were placed at other houses pending the return of the Wyndhams. ${ }^{25}$

\section{Domestic relations}

Many servants, at the turn of the twentieth century, had a tradition of service. They were born into a serving class and, on some English estates, their families had been in the service of a single, gentry family for several generations. This was not necessarily considered bad. 'Many a butler and nurse or maid', as Oliver Lyttleton noted, 'were the trusted and loved friends of the family [who] taught the youth the standards that were expected of them, and who of my generation did not learn to fish or shoot from some keeper and absorb from him some of the lore and the lessons of the countryside?' (Chandos 1962: 28). Importantly, there are few servants' diaries or accounts to balance the view from the top. None have been found for Wyndhams.

The servant problem, Straub (2008) suggests, was as much about intimacy as about class and, in the making of the modern family, servants were fundamental in shaping notions about desire, domesticity and gender. Hyam identified three sources of sexual initiation for upper-class boys - home, school, brothels - and suggests that overwhelmingly 'for many boys the first sexual experience of the opposite sex was with a female servant living in the family home.' (1991: 59) Because they were servants, then all living-in, they were unequal, subordinate and, until the widespread use of underclothes, had been speedily accessible.

Female servants were vulnerable to rape and sexual abuse, not only by their masters, but also male servants. Large houses had many areas, privies and closets, where illicit encounters, possibly involving mostly non-penetrative acts, might take place. (McKeon 2005: 272) One of Lady Leconfield's footmen, the one promptly replaced, was fired for making love in the pantry to one of the housemaids. ${ }^{26}$ However, the point should not be missed that the life of a housemaid was dull and tedious and the attentions may not always have been unwelcomed.

The arrangement of the rooms at Wyndhams, like similar houses, provided for outer/inner, public/private spaces designed to meet the needs of entertaining, the running of the household, and private living. (McKeon 2005: 663) There were two domains under one roof: the family's spaces were separated architecturally from the service sphere. Separate passages and staircases meant that the majority of servants were restricted to specific areas of the house away from the family's private quarters. Here, Hugh's butler, Maud's lady's maid, and the white housemaids, who cleaned the family apartments, were exceptions. The 'houseboys' cleaned the reception rooms and the rest of the house under the sharp eye of the housekeeper. The race/gender boundary in the residence barred the black 'houseboy' from intimate encounters in the private areas of the house. (Anon 1920c: 1)

$25 \quad$ Maud Wyndham to Lady Leconfield, 30 Apr 1909, WSRO: PHA.

$26 \quad$ Lady Leconfield to Maud Wyndham, 14 June 1912, HHA 2/34/45. 
Yet, the Wyndhams, despite the construction of a good amount of social distance, formed quasi-kinship with their staff. Servants were cared for and firmly admonished. But, to a surprising degree, members of the family, including Hugh's mother, became acquainted with the staff during lengthy visits. Her regular enquiries after them show attachment. Moreover, several of the servants were treated as daughters of the house. Alice, their wartime cook, for example, married from Wyndhams, where she had her wedding breakfast, the champagne supplied by Hugh and Maud.

But, of course, not all servants were adopted in this way. Here the picture is opaque. Black people did not enter Parktown except as servants or labourers and were perceived, perhaps solely, in their occupational roles. Moreover, the houseboy was, in many houses, the object of pointed racism. He was, according to a correspondent in The South African Woman, perceived to be dirty, a carrier of disease, including dreaded syphilis, and it was the task of the mistress to 'guard her home and family.' During the immediate post-war period there were calls for the establishment by the Johannesburg municipality of a 'preparatory compound' to 'prepare' houseboys for service. (Anon 1920c: 1) Nothing came of it, perhaps the notion that black men might better be employed on the farms and in the mines resounded. In general, white servants were treated differently. Their work was often less menial and, as butlers, farm managers, and personal maids, they were more closely involved in the lives of their families. This was perhaps also true at Wyndhams. We know more about Wright the butler and considerably less about 'the black boy' who served breakfast and who indeed remains anonymous. ${ }^{27}$

However, bonds of patriarchal affection did not mean that all was domestic bliss. Conflict arose on occasion, between the Wyndhams and their servants and between the servants themselves. There were several reasons for this. Firstly, it was dangerous for a servant to attempt to close the social gap. While the social pretensions of servants were amusing, they were not taken seriously. ${ }^{28}$ Such servants were tolerated as long they served well. But there was always also a balance of considerations for a personal servant (a butler or a lady's maid) was expected to study the habits of the employer and anticipate every need. However, all-hearing, all-seeing servants brought the risk of gossip, something that was rife among Johannesburg's socialites. Maud, on occasion, complained to her mother of Mary Drew, Gladstone's widowed sister, who loved intrigues and 'diddle diddles of any kind.' She 'tells her maid everything \& gets her to tell her - what our servants thought of us for instance - \& any little thing she harps on for ever. ${ }^{29}$ This was unforgivable, especially as Hugh was a particularly private man.

Serious, too, was a subtle boycott of the employer's will when the advice of the servant was dismissed, although here the Wyndhams seem to have been very accommodating. Extra staff was hired for large dinners, when this was requested by the butler, and, in 1912, Maud even allowed her servants their request that they have the use of her sitting room on a semi-permanent basis.

Conflict was seemingly more frequent between the servants, although this normally occurred while Maud was away or when a pecking order was being established among (new) servants. The household structure, perhaps the smallest of Cannadine's 
interlocking hierarchies, was rigid. There were strict conventions on what each servant was expected to do. Most servants were accustomed to these conventions and some, such as Light, the parlour maid, refused to do anything out of their routine. Maud, at various times, encountered protests, the conflict seemingly caused by a blurring of duties, of which servant was expected to do what, and a difference between English etiquette and South African practice. Clearly practice influenced convention and created a hazy arena for domestic strife.

Some conflict followed racial lines. The senior servants were invariably white and left the more menial work to their black counterparts (van Onselen 2001: 219), which was not well-received and the normal reaction, according to Gray, was one of 'Me no understand Missis. ${ }^{30}$ Maud seemingly appreciated the complexity of the situation. In April 1912, she recorded that it was 'quite refreshing to see [the white servants] doing things for themselves \& not waiting for a black. ${ }^{31}$ In time the Wyndhams replaced most of their white staff with black men, although largely as an economy. By 1917, the staff had been reduced to a cook and a housemaid, both white, and three 'houseboys.' The housemaid, Georgina Mason, was very hard-working and expected equally exacting work from the 'houseboys.' Sometimes, it would seem, Georgina raised her voice. This led in January 1919 to a deputation, 'consisting of William the pantry boy \& a Zulu houseboy,' to Maud who was seemingly a mutually acceptable arbitrator. ${ }^{32}$

Maud was often asked to intervene, her verdict accepted, if at times perhaps grudgingly, by all of the servants. However, it would seem that her arbitration was most common when there was a disagreement between the senior servants, perhaps a flare in the rather tempestuous relationship between Gray and Wright. Gray, cook for two years, appears to have been the first servant to canvass Maud's support. In April 1912, she and Wright scrapped over jam and the amount of butter the butler used at breakfast. Maud, placed in a difficult position, took the butler's part. She hoped that it would resolve itself, but the ruckus continued. Soon the cook and butler would not speak to each other and, over the next months, Maud continued to be drawn into the storeroom for a tête-à-tête with the Gray, the precipitating event varying from the division of duties to the comments of the other servants on the quality of the food. ${ }^{33}$

Bad cooking, unlike poor housekeeping, was detected immediately. Gray's poor attention to food preparation and its presentation surfaced again and again. The other servants left Wright to take up the matter with her and when he did Gray would approach Maud and pour forth her woes. By late 1912 Maud had had enough and, in December, Maud, for the first time, expressed the thought of dismissing Gray. ${ }^{34}$ She indicated four reasons to Lady Leconfield: Gray was really a bad cook and not up to the place (her soup tasted like something from 'the Pig \& Whistle in a country town'), she complained that the dinner parties broke her down, and, while a bad manager, she was also 'a deadly enemy of Wright's', which had simply become too tiresome. ${ }^{35}$ In January, having been summoned

Maud Wyndham to Lady Leconfield, 8 June 1912, WSRO: PHA.

Maud Wyndham to Lady Leconfield, 7 Apr 1912, WSRO: PHA.

Maud Wyndham to Lady Leconfield, 13 Jan 1919, WSRO: PHA.

Maud Wyndham to Lady Leconfield, undated [c. Aug 1912], WSRO: PHA.

Maud Wyndham to Lady Leconfield, 24 Nov 1912 and 22 Dec 1912, WSRO: PHA.

Maud Wyndham to Lady Leconfield, 22 Dec 1912, WSRO: PHA. 
into the storeroom once more, Maud decided to dismiss Gray after the end of the parliamentary session. This she did and Gray received her marching orders on 1 April 1913.

Pleasant servants, always of primary concern, were a prerequisite for a peaceful household and unobtrusive domestic service. Servants that bickered among themselves were 'rather tiresome' and, no matter how much Maud tried to take no notice, this did have an impact on their efficiency. ${ }^{36}$ However, life below the stairs seems generally to have been happy. Maud, on occasion, noted their 'laughing \& talking among themselves. ${ }^{37}$

Perhaps more tangible was the theft that resulted from poor housekeeping or the bad monitoring of household accounts. Parktown residents seem generally to have been confronted with this problem. The very first issue of The South African Woman reminded its readers in June 1920 'that no one is a housekeeper naturally, but that it is a business and a very complicated one - that has to be learnt like any other.' Housekeeping it went on was just as involved as cooking; the only difference being 'that, whereas bad cooking cannot be hidden, bad management is only detected when it has gone on for some time.' (Anon 1920a: 15) Of all the servants at Wyndhams, the cook, who also kept the household accounts and ordered in the provisions, was particularly well placed to abuse her position. Many employers were less than thorough in their scrutiny of them. But not so Maud: after only a few months at Wyndhams, she dismissed Booker for 'overspending and poor economy. ${ }^{38}$ The cook naturally fell back on poor billing or, as Gray did, the iniquities of the other staff. Buying, The South African Woman columnist continued, was one of the most important branches of housekeeping. It actively combated theft and gave the housewife the added advantage of discovering daily what was cheap, enabling her to take advantage of the market. (Anon 1920a: 15)

\section{COMPENSATIONS FOR SERVICE}

But what compensations were there for domestic service? McBride has argued that some servants had high aspirations. (McBride 1976: 95) For the Wyndham servants aspirations varied markedly. For some there was attachment to a good, respectable family and the mobility this might offer in terms of benefits and specialisation and a future move to an even better household. For others there was a measure of economic security; without other options, they could have the benefit of free board and lodging, a relatively safe environment, and the opportunity to save money. Such savings enabled several Wyndham servants to make a transition into society, either as a dowry or to start a commercial venture. Some servants may have been attracted by the lifestyle offered in terms of travel and the opportunity to brush shoulders with the elite. (van der Waag 2007: 283-85)

\section{ECONOMIC DOWNSCALING}

The outbreak of the Great War ushered in a new sense of purpose and, with it, a drive to greater economy, which was necessary and seen as patriotic. Life at Wyndhams changed immediately. Hugh and Maud, who lived largely on income from Britain, which was now

\footnotetext{
$36 \quad$ Maud Wyndham to Lady Leconfield, 8 July 1912, WSRO: PHA.

$37 \quad$ Maud Wyndham to Lady Leconfield, 8 June 1912, WSRO: PHA.

$38 \quad$ Maud Wyndham to Lady Leconfield, 26 Feb 1909, WSRO: PHA.
} 
threatened, decided to live quietly. They husbanded resources for they would now have to live on Hugh's parliamentary salary of $£ 400$ per year and revenue generated by Kromdraai and Hugh's coal interests. The parties ended. They gave up their motorcar in 1914, when their chauffeur was called-up.

Kromdraai was also brought onto a war-time, profit-making basis. More farmland was put under crops. Wyndham sold his stable in 1917. The Ayrshire herd followed. Hugh planned to focus on crops and beef cattle and pigs, but rain, either too little or too much, interfered with farming operations, reduced the harvest and the flow in Wyndham's purse. He and Maud took forced and voluntary cost-cutting measures, which he used to assure her were impossible to a born Wyndham. ${ }^{39}$

\section{[INSERT FIGURE 2]}

This economising was facilitated by a third impact of the war, also felt immediately: the departure of servants for the front. By October 1914, no less than six servants had left the Wyndhams employ for this reason. Hundreds of pounds were saved each year; while they could also be seen to be doing their bit, forgoing the pre-war high life and luxuries. As is shown in figure 2, by mid-1917, the staff at Wyndhams was reduced to two white and three black servants in addition to a black gardener, which brought a saving on the house in Parktown, in wages alone, of between $£ 510$ and $£ 520$ a year. ${ }^{40}$ The reduced lifestyle with fewer servants suited the Wyndhams financially and they could feel to be making the necessary wartime sacrifices and so share the deprivations suffered by relatives in Britain. The war was certainly a great leveller.

If the British world was elated following the armistice in 1918, the gentry, less pleased, braced themselves for the inevitable post-war changes. Some English aristocrats forecast a wave of revolutions. Maud's Aunt Henrietta prophesied revolutions both in Britain as well as on the imperial periphery. The English would be driven from South Africa, while Britain itself would be convulsed by 'a revolution like the French one. ${ }^{41}$ Maud's father, marginally more optimistic, catalogued the immediate concerns: the prospect of a Labour government in Britain, the inability to reach a settlement, both in Ireland and with regard to Tariff Reform, and the range of labour troubles. 'The real world threat', he told Maud, was now 'Bolshevism, which if we do not take care, may menace civilisation as much as Hun militarism ever did. ${ }^{42}$

The discomfort, always emotive, was often material. The world had changed, politically, socially, economically. Country houses and town residences closed across the empire. In South Africa, Charles Leonard sold Gloria, Arcadia, the Phillips residence in Pretoria, was on the market, and Bedford Farm, the Farrar country house, was sold for use as a girls' school. Although the Wyndhams still travelled (increasingly for business, not solely for pleasure), appointed servants and occasionally bought paintings, they, too, scaled down. Wyndhams was leased from February 1919 and Kromdraai House, already in a poor

\footnotetext{
$39 \quad$ Maud Wyndham to Lady Leconfield, 24 Sep 1917, WSRO: PHA.

$40 \quad$ Maud Wyndham to Lady Leconfield, 21 July 1917, WSRO: PHA.

41 Lady Cobham to Maud Wyndham, undated, HHA 5/12/19.

42 Lord Cobham to Maud Wyndham, 17 Nov [1918], HHA 2/31/61A.
} 
state in 1915, was demolished in July 1920 and a 'less pretentious dwelling' was built. ${ }^{43}$ Hardened finances caused Maud to scrutinise the household accounts more closely and it was not long before she found something was amiss and the cook, who had been 'disposed to drink from the grocer's bill', was fired. ${ }^{44}$ 'The marvellous cheapness \& comfort of pre war days', Maud recognised, had gone and with it the carefree, leisured life played out by migrant aristocrats somewhere on the imperial periphery. ${ }^{45}$ A sequence of events, some socio-economic, others political, commencing with the general election in March 1920, when Hugh lost Turffontein to 'a labour man', seemed cumulatively to point to the end of an era.

Two domestic matters concerned women like Maud in the more democratic, postwar Johannesburg. The first was a perceived 'general inefficiency on the part of white domestics.' This subject, a correspondent in the South African Woman warned readers, was 'big and complicated, bristling with difficulties.' (Anon 1920b: 1) The women who came into domestic service were untrained, which highlighted the need for training schools, although the onus was also on the employers to provide suitable, in-service, training. Moreover, as a Miss van der Merwe of Johannesburg argued, it was thought that improved living and working conditions would lead to better efficiency. (van der Merwe 1920: 6-7) The second matter, perhaps more disconcerting, was an apparent trend for 'women in need of employment [to] object to housework.' (Anon 1921a: 1) Women arriving in Johannesburg, in many cases as part of the 'trek to the cities', were in need of employment. But these women, used to the relative freedoms of the platteland, objected to the 'sleepingin' arrangements associated with city domestic work. Although schemes were mooted, for a national domestic-training college, improved working conditions, and legislative regulation, little changed and 'supply and demand [remained] out of gear.' Many white servants also disliked having to do more menial tasks, which meant that a houseboy still had to be kept for scrubbing, cleaning boots, and other unpleasant tasks. (Anon 1921a: 1)

\section{[INSERT FIGURE 3]}

The answer seemingly came in the form of greater domestic automation. The variety and quality of domestic machinery, as shown in figure 3, grew dramatically during this period. The modern woman was now a 'woman of affairs' and, in order to get through her work, she had to become 'a household engineer.' (Anon 1921b: 10) American housewives were admired for the way in which they embraced these technologies. As The South African Woman noted in 1921,

'One of the mistakes that can justly be laid at the door of the majority of colonial housekeepers is the fact that they do not make use of labour-saving machines and other devices.' (Anon 1921b: 10)

The advent of the sewing machine (1851), the washing machine (rotary 1858, electric 1908), the dishwasher (1886), the compact, modern vacuum cleaner (1901) and the refrigerator (1911) reduced the need for a large, differentiated staff of laundry maids, housemaids and scullery maids. These appliances were readily available by 1914 and in widespread use by the 1940s. They were joined by the pop-up toaster (invented 1919), frozen foods (by 1930), and

\footnotetext{
$43 \quad$ Hugh Wyndham to Lady Leconfield, 2 May 1920 and 27 Jul 1920, WSRO: PHA.

$44 \quad$ Maud Wyndham to Lady Leconfield, 3 May 1921, WSRO: PHA.

$45 \quad$ Maud Wyndham to Lady Leconfield, 19 May 1920, WSRO: PHA.
} 
the tumble dryer (1931), culminating with the food processor and a host of other labour-saving devices by the 1970s. 'Every woman', the anonymous correspondent exhorted in 1921, 'should bear in mind that by using every possible labour-saving machine that is available, she becomes to a very great extent independent of the very inefficient service that is all one can hope for in these disorganised days.' (Anon 1921b: 10)

Much changed too for servants during the years following the world wars, although, globally, migrants continued to predominate in the white, domestic-service sector, which remained also an occupation of short duration and high turnover. (Moya 2007; Sager 2007: 509-37) Nevertheless domestic work was transformed by a feminisation of the domestic servant occupation (Moya 2007: 559-79) as well as the automation of housework. Labour was replaced with new household technologies. (Hamill 2006, 241-9) Moreover, the trend away from live-in servants, who had been isolated, aided the political mobilisation of domestic servants in South Africa in the 1980s. (Gaitskell, Kimble, Maconachie \& Unterhalter 1983: 86-108) At the start of the twenty-first century South Africa is seemingly set to follow another world trend - the gradual replacement of the wage-paid domestic servant by the unpaid housewife or, increasingly, the unpaid househusband.

\section{CLOSING THE KITCHEN DOOR}

Hugh Wyndham arrived in South Africa in 1901, at a time when Britain and things English seemed indestructible. He and Maud left in 1923, when the march of both militant labour and Afrikaner nationalism seemed unstoppable. The British world had undergone a dramatic transformation. The pre-war empire had been a vast, unequal world, with a layered, interconnected, social hierarchy. Society had been divided, rather rigidly, into the servant keeping and serving classes. It was a time, as one of Maud's cousins noted, when it was easy to distinguish a duchess from a housemaid. (Chandos 1962: 27) South African society at the start of the twentieth century had also been layered. Society cascaded down from Government House and the migrant nobles in orbit around the proconsul, through to the local gentry and gentlemen farmers, many of whom were represented in parliament and the provincial and municipal councils, to the white electorate and the officials of Native Affairs Department, the magistrates, chiefs and headmen. But, if this layering was essentially hierarchical at first, it was done increasingly and solely according to race, as had happened among the servants in the Wyndham household. Life, in the immediate post-war years, seemed suddenly far more ambiguous.

The divisions between master and white servant narrowed in a more democratic, post-war world. Economic pressures placed limits on the leisure activities of the heretofore idle gentry, who now travelled less for pleasure and had to exert themselves in uncomfortable business arenas. Less disposable income brought a cramped lifestyle. Pursuits were now less acquisitive. Fewer travelling visitors were received at their houses, which became smaller and vastly reduced in terms of household staff. In South Africa there were fewer white servants in particular, as race surpassed class in defining master-servant relations.

In the Wyndham household, Maud dealt primarily with these ambiguities first hand. She, more than Hugh, occupied a place in the social and domestic hierarchy where concerns about race, class and gender connected and incongruities between the ideals of empire and the notions of colonial gentry, on the one hand, and the practical needs of maintaining a gentrified lifestyle in a changing South Africa were uncomfortably felt. Society had changed. A 
succession of political, social and economic transformations, brought on by the challenges of the industrial revolution, the rise of the middling classes and the attendant succession of legislation could neither be resisted nor reversed by the servant keepers. Contestation inevitably entered their homes as both public and private figures.

\section{REFERENCES}

Ally, S. 2009. From Servants to Workers; South African Domestic Workers and the Democratic State. Ithaca, Cornell University Press.

Anon. 1908. 'Marriage of the Hon. Maud Lyttelton; Brilliant Ceremony in London.' The

Times, London, c.Feb.

Anon. 1920a. 'The Housekeeper.' The South African Woman, 1(1) Jun: 15.

Anon. 1920b. 'White Domestic Servants.' The South African Woman, 1(2) Jul: 1.

Anon. 1920c. 'The Houseboy.' The South African Woman, 1(6) Nov: 1.

Anon. 1921a. 'Don't Want Housework.' The South African Woman, 1(8) Jan: 1.

Anon. 1921b. 'The Housekeeper; Should Your Laundress Strike.' The South African Woman, 1(9) Feb: 10.

Blackwell, P. 1981. “'An Undoubted Jewell”: a case study of five Sussex country houses, 1880-1914.’ Southern History, 3: 183-200.

Burke. 1891/95. Burke’s Colonial Gentry, vols 1-2. London: Burke’s Peerage.

Bush, J. 1994. "“The Right Sort of Woman”: female emigrators and emigration to the British Empire, 1890-1910.’ Women's History Review, 3(3): 385-409.

Cannadine, D. 1996. The Decline and Fall of the British Aristocracy. London, Basingstoke: Macmillan.

Cannadine, D. 1998. Class in Britain. Newhaven: Yale University Press.

Cannadine, D. 2002. Ornamentalism: How the British saw their Empire. London: Penguin.

Chandos, Lord (Oliver Lyttelton). 1962. The Memoirs of Lord Chandos. London: The Bodley Head.

Cox, A.F. 1920. 'The Servant Question.' The Church Chronicle, 17(2) Jan: 17-18.

Dagut, S. 1997. 'Paternalism and social distance: British settlers' racial attitudes, 1850s1890s.' South African Historical Journal, 37: 3-20.

Darwin, J. 1997. 'Imperialism and the Victorians: The Dynamics of Territorial Expansion.' English Historical Review, 447: 614-42.

Egremont, Lord. 1969. Wyndham and Children First. London, Melbourne, Toronto: Macmillan.

Gaitskell, D., Kimble, J., Maconachie, M. \& Unterhalter, E. 1983. 'Class, race and gender; domestic workers in South Africa.' Review of African Political Economy, 10(27): $86-108$.

Hamill, L. 2006. 'Controlling Smart Devices in the Home.’ The Information Society, 22: $241-49$.

Haskins, V. 2001. 'On the Doorstep; Aboriginal Domestic Service as a "Contact Zone”.' Australian Feminist Studies, 16(34): 13-36.

Horn, P. 1975. The Rise and Fall of the Victorian Servant. New York: St Martin's Press.

Hyam, R. 1991. Empire and Sexuality: The British Experience. Manchester: MUP.

Hyam, R. 1993. Britain's Imperial Century, 1815-1914: A study of Empire and Expansion. Basingstoke, London: Macmillan. 
Jacobs, M.D. 2007. 'Working on the domestic frontier; American Indian domestic servants in white women's households in the San Francisco Bay Area, 1920-1940.' Frontier, A Journal of Women Studies, 28(1): 165-99.

Martinez, J. 2007. 'When wages were clothes; Dressing down aboriginal workers in Australia's northern territory.' International Review of Social History, 52(2): 27186.

Marwick, A. 1965. The Deluge; British Society and the First World War. Boston, Toronto: Atlantic Monthly Press.

McBride, T.M. 1976. The Domestic Revolution: Modernisation of Household Service in England and France, 1820-1920. London: Croom Helm.

McKeon, M. 2005. The Secret History of Domesticity: Public, Private, and the Division of Knowledge. Baltimore MD: Johns Hopkins University Press.

Moya, J.C. 2007. 'Domestic service in a global perspective; Gender, migration and ethnic niches.' Journal of Ethnic and Migration Studies, 33(4): 559-79.

Riedi, E. 2002. 'Women, Gender, and the Promotion of Empire: The Victoria League, 1901-1914.' The Historical Journal 45(3): 569-99.

Royle, E. 1987. Modern Britain; A Social History, 1750-1985. London: Edward Arnold.

Sager, E.W. 2007. 'The transformation of the Canadian domestic servant, 1871-1931.' Social Science History, 31(4): 509-37.

Stone L. \& Fawtier Stone, J.C. 1986. An Open Elite? England, 1540-1880. Oxford: OUP.

Straub, K. 2008. Domestic Affairs: Intimacy, Eroticism, and Violence Between Servants and Masters in Eighteenth-Century Britain. Baltimore MD: Johns Hopkins University Press.

Turner, E.S. 2001. What the Butler Saw: 250 Years of the Servant Problem. Harmondsworth: Penguin.

Van der Merwe, M. 1920. 'White Domestic Servants; A Plea for Better Conditions.' The South African Woman, 1(2) Jul: 6-7.

Van der Waag, I. 2002. 'Hugh Archibald Wyndham (1877-1963): His ancestry and family connections.' Historia, 47(1): 315-44.

Van der Waag, I. 2003. 'Hugh Wyndham, Transvaal Politics and the Attempt to Create an English Country Seat in South Africa, 1901-14.’ In K. Fedorowich \& C. Bridge (eds.), The British World: Diaspora, Culture and Identity. London: Frank Cass.

Van der Waag, I. 2007. 'Domesticity and Servitude: The Wyndham households in Parktown and at Kromdraai, 1903-1923.' Journal of Family History, 32(3): 25995.

Van Onselen, C. 2001. New Babylon New Nineveh; Everyday Life on the Witwatersrand 1886-1914. Johannesburg, Cape Town: Jonathan Ball Publishers.

Wyndham, M., ed. 1912. Correspondence of Sarah Spencer Lady Lyttelton 1787-1870. London: John Murray.

Wyndham, M. 1924. Chronicles of the Eighteenth Century. Founded on the Correspondence of Sir Thomas Lyttelton and his Family, 2 vols. London: Hodder.

\section{Private papers}

Letters from Hugh and Maud Wyndham to his mother from Africa, Petworth House Archives, West Sussex Record Office, Chichester, UK

Letters from Maud Wyndham to her parents, Hagley Hall Archives, Worcestershire, UK 
Patrick Duncan Papers, University of Cape Town Libraries Masterman Papers, University of Birmingham Libraries

Maxse Family Papers, West Sussex Record Office, Chichester, UK

\section{BIOGRAPHICAL NOTE}

Ian van der Waag is an associate professor in the Faculty of Military Sciences, Stellenbosch University. A transnational historian, his interest in modern African history has lead him to produce the first survey of the military history of twentieth-century South Africa (appearing 2011) as well as to the editorship for the forthcoming, two-volume, Encyclopaedia of African Colonial Conflict with ABC-CLIO (Greenwood 2013). He has published recently on domesticity in the Journal of Family History, war literature in the Journal of Contemporary History, and the politics of colonial command in Soldiers and Settlers. 